\title{
STRATEGI PR INDONESIA DALAM MEMBANGUN CORPORATE REPUTATION MELALUI EVENT JAMBORE PR INDONESIA (JAMPIRO)
}

\author{
Aldilla Evriyana ${ }^{1}$, Heni Indrayani ${ }^{\mathbf{1}^{*}}$ \\ ${ }^{1}$ Universitas Dian Nuswantoro Semarang \\ *Email: heni.indrayani@dsn.dinus.ac.id
}

\begin{abstract}
In establishing an excellent corporation's reputation, $P R$ Indonesia, an Indonesian public relations magazine company, holds an award event every year, the Jambore PR Indonesia. This jamboree event is for all Indonesian public relations figures, both public relations who work for the government and private companies. However, during Covid-19, this event's euphoria could not be felt entirely even though PR Indonesia had tried to establish its reputation by innovating the event virtually online. Therefore, this study aimed to explore PR Indonesia's strategy in establishing corporate reputation from a virtual event, Jambore PR Indonesia (JAMPIRO), by using corporate reputation theory, event theory, and virtual event. The qualitative method was applied to this research. Interpretative research paradigm and cases study approach were also used. The data collections were obtained by using observation, interview and documentation. The research results showed that PR Indonesia had several strategies to build corporate reputation. They conducted city tours, researched public relations' issues, and discussed with public relations specialists to find new ideas and used $P R$ 's Icon as brand reputation. Those corporate reputation strategies created the JAMPIRO event, which was promoted in offline and online media. Looking for event references, keeping participants' trust, and holding JAMPIRO events in various cities were also the other strategies. Hence, during the Covid-19 pandemic, PR Indonesia invented many innovations by creating virtual events to maintain its reputation. The maneuverings were to run online promotions, find virtual event references, create innovative events, determine the virtual event's criteria and hold the low-cost event.
\end{abstract}

Keywords: Corporate Reputation; JAMPIRO Event; PR Indonesia's Strategy; JAMPIRO Virtual Event

\begin{abstract}
ABSTRAK
PR Indonesia dalam membangun reputasi perusahaan mengadakan acara berkonsep penghargaan yang dikemas dengan nama Jambore PR Indonesia kepada insan PR di Indonesia, baik humas perusahaan maupun humas pemerintah setiap tahunnya. Namun, sejak pandemi Covid-19, euforia kompetisi Jambore PR Indonesia semakin berkurang meski PR Indonesia telah mencoba berinovasi menyelenggarakan acara secara virtual untuk menjaga reputasinya. Oleh karena itu, penelitian ini bertujuan untuk mengetahui bagaimana strategi PR Indonesia dalam membangun corporate reputation melalui event dan virtual event Jambore PR Indonesia JAMPIRO dengan menggunakan teori corporate reputation theory, event theorys dan virtual event. Penelitian ini menggunakan metode penelitian kualitatif, dengan paradigma penelitian interpretif serta pendekatan studi kasus. Hasil penelitian ini diperoleh melalui teknik observasi, wawancara dan dokumentasi. Penelitian ini menunjukan bahwa PR Indonesia dalam membuat strategi corporate reputation antara lain dengan melakukan city tour, melakukan riset isu kehumasan, berdiskusi dengan praktisi PR untuk menemukan gagasan baru, menggunakan Icon PR sebagai brand reputation. Selain itu, strategi corporate reputation tersebut menghasil event JAMPIRO dengan strategi melakukan promosi secara offline dan online, mencari referensi event, menjaga trust peserta, mengadakan event JAMPIRO di berbagai Kota. Berkaitan dengan pandemi covid-19 PR Indonesia juga memiliki inovasi dengan membuat virtual event agar reputasi perusahaan tetap berjalan dengan baik yaitu menggunakan beberapa strategi antara lain melakukan promosi melalui online, mencari referensi event secara virtual, melakukan inovasi event, menentukan kriteria virtual event dan mengadakan event dengan biaya murah.
\end{abstract}

Kata kunci: Corporate Reputation; Event JAMPIRO; Strategi PR Indonesia;

Virtual Event JAMPIRO;

Submisi: 16 Juli 2021

KINESIK Vol. 8 No. 2 (2021) | 110 


\section{Pendahuluan}

Pandemi covid 19 di awal 2020 berdampak pada semua aspek kehidupan, termasuk dalam eksistensi bisnis korporat. Kondisi ketidakpastian menuntut korporat berinovasi dalam menjalankan aktivitasnya, terutama digitalisasi komunikasi. Perusahaan yang semula aktivitasnya dijalankan secara langsung atau offline, terpaksa harus beralih ke online. Hal tersebut menjadi sebuah tren baru di dunia korporasi yaitu bisnis digital. Oleh sebab itu diperlukan strategi digitalisasi komunikasi selama pandemi agar tercipta komunikasi yang efektif. Strategi komunikasi harus mencakup segala sesuatu yang dibutuhkan oleh perusahaan. Maka, melakukan komunikasi dibutuhkan elemen-elemen penting yang harus diperhatikan saat melaksanakan strategi komunikasi, seperti komunikator, pesan, media, komunikan, dan tujuan (Bungin, 2015). Suatu perusahaan membutuhkan peran komunikasi yang aktif agar dapat menarik simpati publik atau stakeholder.

Adanya strategi komunikasi yang dilakukan suatu perusahaan dapat meningkatkan reputasi. Reputasi dapat berjalan dengan baik jika perusahaan dapat menjaga eksistensi dan kosistennya dengan baik. Reputasi dan komunikasi sangat erat kaitannya, karena komunikasi masuk dalam sesuatu yang perlu dilakukan dalam membentuk reputasi organisasi maupun perusahaan yang dikelola oleh seorang public relations (Mariana, 2012:2). Maka, reputasi memiliki peran penting dalam berbisnis. Mengkomunikasikan tujuan, target, dan strategi kepada eksekutif dan memberikan rasa aman pada eksekutif adalah fungsi peran Public Relations lainnya (Indrayani, Nurlita, \& Fitriani, 2020).

Strategi komunikasi yang sangat dibutuhkan oleh perusahaan yaitu harus memiliki suatu program atau event yang berkelanjutan. Nantinya dapat membentuk reputasi perusahaan (corporate reputation) yang baik dimata stakeholder. Event merupakan suatu kegiatan yang membutuhkan peran dari berbagai pihak mulai dari mencari vendor hingga stakeholder. Tujuan suatu perusahaan dalam menyelenggarakan event selain perusahaan lebih dikenal terhadap khalayak, juga untuk mempertahankan reputasi (Puspitasari \& Dkk, 2017:117). Diadakannya suatu event secara berkelanjutan, dapat memperoleh positioning yang baik dimata stakeholder atau publik. Akibatnya event tersebut menjadi sebuah ciri khas dari perusahaan sehingga mudah diingat oleh masyarakat.

Berkaitan dengan pandemi, berbagai perusahaan yang memiliki program event secara offline berpindah menjadi virtual event. Dilansir dari sindonews.com, virtual event dimasa yang akan datang memiliki prospek yang baik karena setiap perusahaan dapat melaksanakan event-nya dalam format virtual dengan tidak mengurangi tujuan dari event tersebut (Marsyaf, 2020). Selain itu, virtual event tidak memakan biaya yang besar seperti event offline pada umumnya, dan peserta juga dapat mengikuti rangkaian event dimanapun. Walaupun demikian, perusahaan harus mampu mengelola konsep secara digital melalui berbagai ide kreatif agar memperoleh tujuan yang diharapkan.

Pentingnya event dalam membangun reputasi juga dilakukan oleh PR Indonesia sebagai entitas media yang diterbitkan oleh PT Media Piar Indonesia. Dengan tagline Beyond Reputation, PR Indonesia mengadakan berbagai macam program dalam menguatkan reputasi perusahaan. Salah satunya yaitu, program atau event yang sudah ada sejak berdirinya PR Indonesia yaitu JAMPIRO. Di tahun pertama hingga tahun 2017 event jambore ini disebut JAMMPIRO (Jambore Media \& PR Indonesia) hingga tahun 2017 yang memiliki tujuan sebagai gathering tahunan praktisi PR dan media se-Indonesiaa dari beragam usia, latar belakang korporasi dan 
organisasi yang dikemas dengan multi event. Namun, mulai tahun 2018 hingga 2020 berganti nama menjadi JAMPIRO (Jambore PR Indonesia) dengan tujuan merekatkan dan menghubungkan mulai dari level mahasiswa hingga level atasan seperti direktur sehingga ada kesinambungan.



Gambar 1. Data Peserta Event JAMPIRO PR Indonesia tahun 2015-2020

Sumber: wawancara penyelenggara event JAMPIRO

Dari data tersebut menunjukkan bahwa eksistensi event JAMPIRO selalu dinanti setiap tahunnya oleh para peserta. Dilihat dari data tersebut jumlah peserta 3 tahun terakhir meningkat 50\%. Namun, di tahun 2019 mengalami penurunan sebanyak 25\%. Hingga di tahun 2020 mengalami penurunan peserta yang mengikuti kompetisi JAMPIRO \#6. Penyelenggaraan virtual event ini mengalami kendala seiring dengan masih beradaptasinya dengan teknologi. Dengan menurunnya peserta di JAMPIRO di dua tahun berturut-turut, membuat peneliti ingin mengetahui bagaimana strategi PR Indonesia dalam membangun reputasi perusahaan melalui event Jambore PR Indonesia (JAMPIRO).

Penelitian terdahulu melihat corporate reputation dalam melihat kepuasan target audiens (Risna, 2019). Kemudian penelitian Alexander (2019) juga membahas dari sisi reputasi dalam pembelian ulang. Berbeda dengan penelitian ini yang menambahkan suatu virtual event didalam corporate reputation untuk sebelumnya, kebaruan pada penelitian ini membahas bagaimana corporate reputation dibangun melalui event baik offline maupun virtual Maka dari itu, tujuan dari penelitian ini adalah untuk mengetahui bagaimana strategi PR Indonesia dalam membangun corporate reputation melalui event dan virtual event Jambore PR Indonesia (JAMPIRO).

\section{Corporate Reputation Theory}

Reputasi sangat erat kaitannya dengan perusahaan. Tanpa adanya reputasi, perusahaan tidak dapat mengukur sejauh mana perusahaan tersebut berkembang apakah menuju arah yang lebih baik ataupun sebaliknya. Pengukuran tersebut dilakukan dengan menilai perusahaan dari sudut pandang stakeholders. Corporate reputation berbeda dengan corporate image, Walker mengatakan bahwa walaupun hasil dari corporate reputation dan corporate image saling berkaitan dengan seluruh stakeholder baik internal maupun eksternal, namun pada kenyataanya proses dalam membentuk image atau reputasi berbeda (Risna, 2019:17).

Berdasarkan pada tabel diatas, menunjukan bahwa corporate image hanya fokus pada stakeholder secara eksternal. Hal ini menunjukkan bahwa masyarakat sangat erat kaitannya dengan citra perusahaan. Citra biasanya dibentuk saat perusahaan sedang berdiri atau berkembang. Namun, corporate reputation fokus secara keseluruhan baik internal maupun eksternal. Sementara itu, reputasi menuntut perusahaan agar dapat membangun dan mempertahankan reputasi dengan baik. Menurut Rayner reputasi memiliki rumus sebagai acuan dalam membentuk reputasi yang baik:

Reputation $=$ Experience - Expectation

Dalam rumus diatas dijelaskan bahwa, untuk memperoleh reputasi yang baik diperlukan pengalaman yang baik serta perusahaan harus mampu memenuhi serta melebihi ekpektasi dari stakeholders sehingga dapat diperoleh hasil reputasi yang diharapkan oleh perusahaan (Syahriani \& 
Tabel 1. Perbedaan Corporate eputation dan Corporate Image

\begin{tabular}{|l|l|l|}
\hline Jenis & Corporate Image & Corporate Reputation \\
\hline $\begin{array}{l}\text { Stakeholder: Internal atau } \\
\text { Persepsi: yang diinginkan atau } \\
\text { aktual }\end{array}$ & Eksternal & Internal dan Eksternal \\
\hline $\begin{array}{l}\text { Emanasi dari dalam atau luar } \\
\text { perusahaan }\end{array}$ & Dalam & Aktual \\
\hline $\begin{array}{l}\text { Kemungkinan persepsi bagi } \\
\text { perusahaan: positif atau negatif }\end{array}$ & Positif & Dalam dan luar \\
\hline $\begin{array}{l}\text { Pertanyaan relevan } \\
\text { (a) Apa yang ingin } \\
\text { orang lain pikir } \\
\text { tentang kita?" }\end{array}$ & "Kita terlihat seperti \\
\end{tabular}

Sumber (Risna, 2019:17)

Siwi, 2018:58). Reputasi dapat menjadi baik atau buruk tergantung pada strategi, komitmen, serta kualitas dari perusahaan untuk mencapai tujuan melalui berbagai program yang telah direalisasikan (Adhrianti, 2018:1018).

\section{Event Theory}

Event adalah sebuah kegiatan yang dirancang dengan tema tertentu yang bertujuan untuk menarik perhatian peserta dan mengambil pesan yang ingin ditampilkan oleh perusahaan (Rahma, 2017:157). Hal ini dilakukan untuk memudahkan bagi pembuat event dalam menciptakan sebuah acara yang sesuai dengan tujuan. Menurut Lidia event memiliki beberapa manfaat (Puspitasari \& Dkk, 2017:117) yaitu memperoleh informasi yang benar mengenai produk atau jasa yang baru diluncurkan, menunjukkan eksistensi dan menunjukkan kekuatannya dimata pesaing dan menjaga image dan reputation produk atau jasa, dengan menyelenggarakan event.

Event juga salah satu media komunikasi, sebab didalam suatu event memiliki berbagai kegiatan yang mencakup banyak orang. Menurut Getz, event dibagi menjadi beberapa jenis, antara lain (1). Attraction. Event merupakan daya tarik tersendiri bagi target audiens dan sebagai kegiatan yang menarik untuk dinikmati. (2). Image Maker. Perusahaan dapat memasarkan programnya melalui event untuk membentuk citra positif bagi perusahaan. (3). Animators of Static Attractions. Dapat menunjukkan atraksi sebagai ajang kreativitas bagi si pembuat event. (4). Catalyst for Other Development. Merupakan penggerak tumbuhnya sektor lain agar membantu melengkapi kegiatan yang diselenggarakan. Selain itu, event juga memiliki beberapa kategori (Noor, 2009), meliputi mini event, medium event dan mega event. Mini Event adalah suatu kegiatan yang diikuti kurang dari 100 ribu pengunjung dan bersifat lokal. Kemudian, Medium Event yaitu suatu kegiatan yang diikuti oleh antara 100 ribu pengunjung hingga satu juta pengunjung dalam taraf nasional. Minimal dihadiri oleh satu juta pengunjung. Sedangkan Mega Event merujuk pada kegiatan internasional, dengan minimal 5 negara yang hadir dalam event tersebut. Semakin banyak negara yang hadir, semakin banyak pula investasi, relasi, dan keuntungan yang lebih besar sehingga berdampak besar bagi ekonomi masyarakat. di negera tempat event tersebut dibuat.

Virtual Event 
Tabel 2. Perbedaan Virtual Event dan Offline Event.

\begin{tabular}{|c|c|c|c|}
\hline No. & Jenis & Offline Event & Virtual Event \\
\hline 1. & $\begin{array}{l}\text { Pengeluaran } \\
\text { anggaran. }\end{array}$ & $\begin{array}{l}\text { Besar (Pengeluaran hotel, } \\
\text { transportasi, dll). }\end{array}$ & $\begin{array}{l}\text { Kecil (platform, design, } \\
\text { content creator, dll) }\end{array}$ \\
\hline 2. & Pendapatan. & $\begin{array}{l}\text { Sulit (Memakan waktu } \\
\text { biaya sponsor, biaya } \\
\text { kehadiran, dll). Tetapi } \\
\text { pendapatan yang } \\
\text { diperoleh relatif banyak. }\end{array}$ & $\begin{array}{l}\text { Mudah dan cepat } \\
\text { (sehingga dapat investasi } \\
\text { uang dan waktu serta } \\
\text { hanya membayar sesuai } \\
\text { konten, dll). Tapi hanya } \\
\text { memperoleh } \\
\text { pendapatan. }\end{array}$ \\
\hline 3. & Waktu. & $\begin{array}{l}\text { Jika memakan waktu } \\
\text { hingga satu hari penuh } \\
\text { dapat memakan biaya } \\
\text { sewa, dll yang sangat } \\
\text { tinggi. }\end{array}$ & $\begin{array}{l}\text { Jika memakan waktu } \\
\text { hingga satu hari penuh } \\
\text { tidak perlu memikirkan } \\
\text { biaya sewa tempat, dan } \\
\text { biaya sewa platform jauh } \\
\text { lebih murah. }\end{array}$ \\
\hline
\end{tabular}

Sumber (TSNN, 2010:6)

Acara virtual merupakan kegiatan yang melibatkan teknologi internet. Berbicara tentang virtual event hal utama yang wajib diperhatikan adalah digital, sebab platform ada didalam dunia digital (Tzanelli, 2017:6). Memilih platform juga harus memperhatikan beberapa kriteria, yaitu: (1).Flexibility. Membentuk sebuah platform dengan cara yang sesuai kebutuhan perusahaan. Seperti menyesuaikan fitur atau tata letak yang berkaitan dengan acara yang ingin dibuat, sehingga acara dapat sesuai dengan yang diinginkan. (2). Reliability. Platform harus tersedia setiap saat, sehingga panitia dapat monitoring mulai dari sistem pendaftaran, teknis acara hingga lingkungan acara tersebut. (3). Scalability. Kemampuan untuk dapat meningkatkan skala peserta dalam acara tersebut hingga puluhan ribu sesuai dengan kebutuhan (Shiao, 2010:9).

Selain memperhatikan kriteria dari platform, membuat acara virtual juga perlu memperhatikan durasi acara. Virtual event dan offline event memiliki beberapa perbedaan (TSNN, 2010:6).

Berdasarkan tabel diatas, dapat diambil kesimpulan bahwa acara yang diadakan secara offline atau langsung dengan acara yang diadakan secara online berbeda. Dilihat dari pengeluaran anggaran acara yang diadakan secara offline terbilang sangat besar dan banyak seperti anggaran transportasi, tempat, akomodasi, dan lain sebagainya. Sementara anggaran acara online jauh lebih kecil, yang perlu dikeluarkan hanya biaya platform, design, dan content creator. Selanjutnya untuk pendapatan juga berbeda, jika acara offline dalam memperoleh pendapatan relatif cukup sulit namun hasil yang diperoleh cukup banyak. Sebaliknya acara online, dalam memperoleh pendapatan cukup mudah dan cepat, namun hasil yang diperoleh sedikit.

\section{Metode Penelitian}

Penelitian ini menggunakan metode penelitian kualitatif, dengan menggunakan paradigma penelitian interpretif serta menggunakan pendekatan studi kasus. Penelitian menggunakan studi kasus biasa digambarkan sebagai metode yang mudah, menantang, dan dapat digunakan dimana saja serta paling umum digunakan dalam penelitian kualitatif. Selain itu, penelitian 
menggunakan metode kualitatif dipilih karena, untuk menjawab bagaimana strategi komunikasi PR Indonesia dalam membangun corporate reputation melalui event JAMPIRO, serta untuk mengumpulkan, menganalisis dan mengolah data hasil dari penelitian.

Subjek dari penelitian ini adalah internal PR Indonesia dan peserta yang ikut terlibat didalam event dan virtual event JAMPIRO 2018 dan 2020. Adapun narasumber dari penelitian ini adalah Founder PR Indonesia, penyelenggara event JAMPIRO, peserta event JAMPIRO 4 yang diadakan secara offline pada tahun 2018 dan peserta event JAMPIRO 6 yang diadakan secara online pada tahun 2020 dengan kategori Insan PR Indonesia, Icon PR Indonesia dan Rookie Star

Data yang diperoleh secara langsung dari lapangan oleh orang yang meneliti, berdasarkan informasi yang diteliti oleh peneliti kepada informan. Data primer diperoleh melalui hasil observasi dan wawancara. Kriteria informan meliputi internal PR Indonesia yaitu founder PR Indonesia dan penyelenggara event JAMPIRO. Informan eksternal meliputi general manager dan manager pemenang kategori insan PR 2018 dan 2020, enam humas muda dari berbagai perusahaan sebagai pemenang kategori Icon PR 2018 dan 2020, serta mahasiswi LSPR dan Universitas Indonesia sebagai pemenang di kategori Rookie Star 2018 dan 2020. Sedangkan data sekunder didapatkan secara tidak langsung atau melalui media sosial, website, artikel, internet, referensi, literatur, buku dan lain sebagainya.

Teknik pengumpulan data sesuai dengan penelitian kualitatif, dapat dilakukan dengan cara observasi, wawancara dan dokumentasi. Analisis data berdasarkan pendekatan studi kasus yaitu menggunakan penjodohan pola untuk memperoleh penjelasan yang lebih mendalam. Analisis data di metode penelitian kualitatif melakukan pengumpulan data saat sedang berlangsung seperti wawancara, observasi dan dokumentasi. Menurut Hubermen, analisa data ada tiga (Sutopo, 2002) yaitu reduksi data, sajian data dan verifikasi.Setelah itu dilakukan penarikan kesimpulan yaitu melakukan verifikasi data secara terus menerus selama proses penelitian berlangsung, yaitu dengan mengamati langsung proses penelitian di lapangan dan membandingkan rumusan permasalahan sesuai dengan keadaan yang sebenarnya. Dalam penelitian ini menggunakan triangulasi data dan triangulasi teori. Dimana triangulasi data digunakan untuk mengumpulkan data sejenis dengan menggunakan berbagai sumber seperti wawancara, observasi maupun dokumentasi. Lalu teori digunakan untuk dapat menarik kesimpulan secara lebih menyeluruh.

\section{Hasil Penelitian}

Penelitian ini dilakukan untuk menguraikan dan menerangkan data hasil penelitian tentang strategi PR Indonesia dalam membangun corporate reputation melalui event Jambore PR Indonesia (JAMPIRO). Penelitian ini menggunakan teori corporate reputation, event theory dan virtual event. Hasil penelitian ini diperoleh dari teknik wawancara terhadap informan yang sudah disesuaikan dengan target penelitian. Wawancara dilakukan melalui email maupun telepon. Lebih lanjut, peneliti menggunakan observasi untuk melengkapi data serta melakukan dokumentasi secara online.

Fokus penelitian ini untuk melihat implementasi dari strategi corporate reputation $\mathrm{PR}$ Indonesia melalui event JAMPIRO. Penelitian dilakukan menggunakan metode kualitatif. Melalui penelitian ini, dipilih 12 narasumber dari berbagai kalangan, diantaranya Founder PR Indonesia, project leader dalam acara JAMPIRO, perwakilan pemenang Insan PR 2018 dan 2020, perwakilan pemenang Icon PR 2018 dan 2020, serta perwakilan pemenang Rookie Star 2018 dan 2020. Peneliti memilih narasumber dari 
Tabel 3. Daftar 12 Narasumber

\begin{tabular}{|c|c|c|c|}
\hline No & Nama & Jabatan & Keterangan \\
\hline 1 & Asmono Wikan & Founder PR Indonesia & Narasumber 1 \\
\hline 2 & Lila Intana & $\begin{array}{l}\text { Event and Training Management PR } \\
\text { Indonesia }\end{array}$ & Narasumber 2 \\
\hline 3 & Muhammad Thwan & $\begin{array}{l}\text { General Manager Public Relations PT. } \\
\text { Petrokimia Gresik }\end{array}$ & $\begin{array}{l}\text { Narasumber } 3 \\
\text { (Bronze } \\
\text { Winner Insan } \\
\text { PR 2018) }\end{array}$ \\
\hline 4 & Zainal Abidin & $\begin{array}{l}\text { Manager Public } \\
\text { Pertamina Gas }\end{array}$ & $\begin{array}{l}\text { Narasumber } 4 \\
\text { (Silver Winner } \\
\text { Insan PR 2020) }\end{array}$ \\
\hline 5 & Eggie Nurmahabibi & $\begin{array}{l}\text { Public Relations Sinergi Informatika } \\
\text { Semen Indonesia }\end{array}$ & $\begin{array}{l}\text { Narasumber } 5 \\
\text { (Icon PR 2018) }\end{array}$ \\
\hline 6 & Erfina Ningsih $P$ & $\begin{array}{l}\text { Public Relations } \\
\text { Parawisata RI }\end{array}$ & $\begin{array}{l}\text { Narasumber } 6 \\
\text { (Icon PR 2018) }\end{array}$ \\
\hline 7 & Laibun Sobri & Public Relations Pocari Sweat & $\begin{array}{l}\text { Narasumber } 7 \\
\text { (Icon PR 2018) }\end{array}$ \\
\hline 8 & Krisna Pandu $\mathrm{P}$ & $\begin{array}{ll}\begin{array}{l}\text { Public Relations } \\
\text { Keuangan RI }\end{array} & \text { Kementerian } \\
\end{array}$ & $\begin{array}{l}\text { Narasumber } 8 \\
\text { (Icon PR 2020) }\end{array}$ \\
\hline 9 & Winda Adelita S & $\begin{array}{l}\text { Public Relations Roundtable on } \\
\text { Sustainable }\end{array}$ & $\begin{array}{l}\text { Narasumber } 9 \\
\text { (Icon PR 2020) }\end{array}$ \\
\hline 10 & Esty Nadya R & Public Relations PT SCG Indonesia & $\begin{array}{l}\text { Narasumber } 10 \\
\text { (Icon PR 2020) }\end{array}$ \\
\hline 11 & Aghnina Wahdini & The London School of Public Relations & $\begin{array}{l}\text { Narasumber } 11 \\
\text { (First Winner } \\
\text { Rookie Star } \\
2018 \text { ) }\end{array}$ \\
\hline 12 & Yessicha R & Universitas Indonesia & $\begin{array}{l}\text { Narasumber } 12 \\
\text { (First Winner }\end{array}$ \\
\hline
\end{tabular}

JAMPIRO 4 di tahun 2018 dan JAMPIRO 6 di tahun 2020 karena, pada tahun 2018 peserta yang mengikuti acara tersebut paling banyak diantara tahun-tahun yang lain. Sementara di tahun 2020, acara JAMPIRO untuk pertama kalinya diselenggarakan secara online. Hal ini untuk melihat apakah reputasi yang dibentuk PR Indonesia melalui acara JAMPIRO baik secara langsung atau offline maupun online tetap mendapat respon positif atau tidak oleh para peserta.

Pengumpulan data primer dilakukan dengan melakukan wawancara secara online dengan seluruh narasumber melalui google meet, whatsapp call, serta mengirimkan daftar pertanyaan melalui email narasumber. Lebih lanjut, peneliti juga memperoleh data sekunder selama observasi berlangsung yang diperoleh melalui media sosial dan website PR Indonesia serta hasil dokumentasi saat wawancara berlansgung. Analisis data dalam penelitian ini menggunakan tiga konsep antara lain implementasi PR Indonesia dalam membangun corporate reputation, implementasi event Jambore PR Indonesia (JAMPIRO), dan implementasi virtual event Jambore PR Indonesia (JAMPIRO). Selain itu, kategori yang digunakan saat penjodohan pola adalah stakeholder, persepsi, emanasi, kemungkinan persepsi, pernyataan relevansi, manfaat, jenis, kategori, kriteria, dan perbedaaan.

\section{Implementasi PR Indonesia dalam Membangun Corporate Reputation}

PR Indonesia, dalam membangun reputasi yang baik di perusahaan menggunakan beberapa aspek. Berikut adalah beberapa aspek yang menjadi indikator penilaian PR Indonesia:

\section{Stakeholder}

Stakeholder dapat diartikan seseorang yang memiliki hubungan dengan perusahaan atau yang biasa disebut pemangku kepentingan (Estaswara, 2020:89). Berdasarkan hasil wawancara dengan Bapak Asmono Wikan selaku Founder PR Indonesia, beliau mengatakan bahwa yang menjadi stakeholder internal yaitu seluruh karyawan yang bekerja dengan PR Indonesia. Sementara stakeholder eksternal PR Indonesia yaitu berasal dari praktisi PR baik dari intansi maupun korporasi. Berkaitan dengan acara 
JAMPIRO, stakeholder eksternal juga menyasar kepada mahasiswa yang ada di seluruh Indonesia.

\section{Persepsi}

Berdasarkan hasil wawancara dengan Bapak Asmono Wikan, dijelaskan bahwa JAMPIRO merupakan kapabiliti PR Indonesia. Sebab acara ini dapat menjadi magnet orang yang ada didekatnya. Seperti meningkatkan atensi dan dapat menjadi penggerak untuk meng-improve kegiatan JAMPIRO. Jika mendapat respon yang bagus maka akan meningkatkan reputasi dan performance, serta barometer perusahan PR Indonesia. Berbeda dari yang dikatakan oleh founder PR Indonesia, Lila Intana selaku project leader PR Indonesia melihat persepsi dari sudut pandang pemberitaan. Ia mengatakan bahwa media sangat tertarik dengan acara JAMPIRO ini. Saat acara berlangsung, eksposure tentang JAMPIRO akan meningkat.

Lebih lanjut, persepsi aktual dari sudut pandang peserta JAMPIRO juga berbeda. Baik acara yang diadakan secara langsung maupun online, ada yang mengatakan positif dan negatif. Rata-rata orang mengatakan negatif berkaitan dengan teknis acara dan juga branding dari acara tersebut. Selebihnya mengatakan positif sebab treatment panitia ke peserta cukup bagus. Perwakilan peserta dari JAMPIRO 4 yang diadakan secara langsung rata-rata mengatakan bahwa acara ini dalam hal teknis perlu dipersiapkan dengan baik, jika perlu dipersiapkan planning yang lain, agar jika ada sesuatu yang tidak terduga dapat di-handle dengan baik. Serta perbanyak media boost untuk acara tersebut agar branding-nya lebih baik lagi. Berdasarkan hasil wawancara dengan peserta JAMPIRO 4 selaku praktisi PR yakni Laibun Sobri - Icon PR 2018 mengatakan bahwa:

"Untuk event JAMPIRO, kalau dilaksanakan offline, mungkin yang paling utama pemilihan bulan dan lokasi, kalau mau outdoor ya pilih bulan yang musim kemarau, overall event-nya sudah menarik karena bekerjasama dengan Pemerintah Kota atau Pemprov, materi yang diberikan juga sudah oke. Untuk PR menurutku, terkait dengan manajemen waktunya harus lebih diatur lagi secara lebih matang, karena Icon pr juga orangnya banyak, jadi Lonya harus lebih ready agar pihak Icon PR tidak kebingungan. Susunan rundown juga harus detail, karena waktu itu gaada rundwn cuman dapet info via wa aja."

Sementara dari sudut pandang mahasiswa saat mengikuti kompetisi Rookie Star 2018 yaitu Aghnina Wahdini, mengatakan:

"Sarannya jangan bikin acara kalo belum siap. Lebih di mapping peserta dari mana aja, jadi disediakan akomodasi lebih baik. Treatment peserta jangan dibedakan. Untuk pemenang alangkah lebih baiknya dikasih reward khususnya Rookie Star. Dari sisi penyelenggaraannya panitia harus siap, harus ngebriefing relawan lebih dalam lagi karena relawan juga masih banyak yang kebingungan. Siapkan plan B kalo tiba-tiba ada kejadian yang tidak terduga. Harus bisa minta maaf ke peserta kalo ada kekurangan. Harus ada form evaluasi untuk perbaikan mereka. Kalo bisa menyediakan pertemuan rutin kalo emang mereka pengen berjejaring. Sebagai pemenang dan peserta pengen dihubungi lagi sama 
mereka dan dapat

keuntungan untuk bertemu sama PR profesional."

Lebih lanjut, persepsi aktual juga diutarakan oleh para peserta JAMPIRO 6 yang diadakan secara online melalui youtube streaming. Rata-rata mengatakan bahwa acara yang diselenggarakan secara online tersebut kurang interaktif dan tidak melibatkan pemenang dalam sesi awarding. Serta branding yang masih kurang menyebabkan public kurang mengetahui lebih dalam tentang PR Indonesia. Seperti yang dikatakan oleh Esty Nadya R salah satu pemenang Icon PR 2020, ia mengatakan bahwa:

"Jujur untuk momen
penganugerahan dan
networking menjadi sangat

kurang karena adanya acara virtual. Dibandingkan dengan JAMPIRO sebelumnya, networking dapat terjalin lebih kuat dan branding atau publikais terkait PR Indonesia pun dapat lebih gencar. Semoga, saya sangat berharap tahun depan JAMPIRO selanjutnya dapat diadakan secara offline dan para pememnang dan tokoh di acara JAMPIRO tahun 2020 ini dapat turut diundang. Overall acaranya sudah oke dan prosesnya pun terbuka. Mungkin akan lebih baik lagi jika peserta juga diinfokan terkait dengan aspek penilaian yang diperoleh serta apa yang perlu dipertahankan atau diperbaiki untuk lebih baik lagi kedepannya. Selain itu, masih perlu adanya further maintenance bagi para pemenang atau pada peserta terpilih untuk tetap menjalin relasi dan mengenal lebih dekat PR Indonesia."
Mempertahankan reputasi perusahaan juga memerlukan persepsi atau gambaran secara aktual. Dapat diambil kesimpulan bahwa persepsi aktual berkaitan dengan acara JAMPIRO baik yang dilaksanakan secara langsung maupun online menunjukkan bahwa peserta merasa pelaksanaan acara JAMPIRO masih cukup banyak kekurangan. Walaupun demikian, mereka merasa bahwa kekurangan tersebut dapat dimaafkan sebab para narasumber memperoleh benefit yang cukup banyak karena menjadi pemenang dari masing-masing kategori yang dikompetisikan. Menurut mereka jika permasalahan teknis dari acara JAMPIRO tidak segera diperbaiki nantinya akan mempengaruhi reputasi perusahaan.

\section{Emanasi}

Berkaitan dengan reputasi perusahaan, emanasi dapat dilihat dari dalam dan dari luar. Berdasarkan wawancara, Bapak Asmono Wikan mengatakan emanasi dari dalam berupa: "Menyangkut portofolio, kinerja, track record, dan persepsi. Memperoleh reputasinya dengan cara mendapatkan persepsi bagus dari market dan komunitas $P R$, karena PR Indonesia hadir untuk mengisi ruang kosong dari kegiatan PR. Seperti membuat acara workshop, dan lain sebagainya. Karena menyangkut kinerja dan protfolio, maka kami akan menimgkatkan itu semua, karena menyangkut kredibiliti seperti isu-isu saat ini seperti komunikasi dimasa pandemi, dan menginformasikan hal-hal yang penting."

Sementara, untuk emanasi dari luar menurut Bapak Asmono Wikan berpendapat: 
"Dari event-event PR

Indonesia peserta selalu meningkat setiap tahunnya. Dari bisnis juga pemasukan iklan selalu meningkat dari tahun ke tahun, serta dari trust. Ukuran-ukurannya kalau peserta yang datang banyak, maka peserta akan trust pada kita, karena kalau datang di acara kita juga dapat relasi baru dan wawasan baru. Jadi ukuran saya sederhana melihat itu, dari angka jelas, mulai dari angka kehadiran narasumber setiap tahun berkembang, kehadiran peserta yang semakin meningkat,

kehadiran iklan yg semakin meningkat."

Berdasarkan wawancara, dapat diambil kesimpulan bahwa emanasi atau pancaran yang diberikan oleh PR Indonesia baik dari dalam maupun luar mampu meningkatkan ketertarikan stakeholder eksternal terhadap event JAMPIRO. Emanasi yang diberikan dari dalam seperti mengumpulkan berbagai portofolio yang nantinya dapat menjadi promosi kepada audiens. Setelah memperbanyak portofolio, nantinya PR Indonesia akan meningkatkan trust stakeholder dengan cara bekerjasama dengan berbagai media agar pemberitaan tetap positif.

\section{Kemungkinan Persepsi}

Berdasarkan hasil wawancara, 7 dari 12 narasumber mengatakan bahwa kemungkinan persepsi PR Indonesia dimata peserta JAMPIRO yaitu positif. Seperti yang dikatakan oleh salah satu narasumber yaitu Winda Adelita sebagai salah satu pemenang Icon PR 2020, mengatakan:

"Sebenernya tidak mengarah ke negatif. Tapi dari dunia PR kan juga membuat event dengan membuat event $y g$ bagu walaupun ditengah

pandemi. PRI kan

perusahaan yg bagus,

perusahaan saya juga sering

buat event jadi malah dibuat

perbandingan. Jadi kurang

interaktif lebh baik dikemas

dengan cara yg baik dan

interaktif. Sebenernya sudah

bagus lebih baik kalo ada

interaksi 2 arah."

Sementara, 5 dari 12 narasumber mengatakan bahwa kemungkinan persepsi PR Indonesia dapat mengarah ke negatif karena berbagai hal seperti teknis acara, treatment panitia dan lain sebagainya. Seperti yang dikatakan oleh pemenang kategori Rookie Star 2020, Aghnina Wahdini:

"Kayaknya berdampak.

Mereka diakhir gaada form

evaluasi. Pasti dari mereka

bisa handle pemberitaan

cuman kalo untuk peserta

banyak yang kecewa. Kalo

dari kepercayaan kami dari

mahasiswa kecewa, mereka

kurang berhasil menciptakan image yang baik ke peserta.

Jadi berdampak ke yang lain."

Kemungkinan persepsi dapat diartikan dengan kemungkinan gambaran atau kemungkinan sudut pandang, dalam hal ini berkaitan dengan gambaran stakeholder internal maupun eksternal yang ada di PR Indonesia. Stakeholder ini berkaitan dengan event JAMPIRO. Kemungkinan menurut KBBI juga memiliki arti keadaan yang memungkinkan sesuatu terjadi. Kemungkinan juga dapat positif dan juga negatif sesuai persepsi masing-masing orang, dalam hal ini stakeholder PR Indonesia.

\section{Pernyataan Relevansi}

Pernyataan relevansi berdasarkan pandangan orang lain terkait event JAMPIRO ada berbagai macam. Berdasarkan hasil wawancara, pandangan penyelenggara event 
JAMPIRO ini mengatakan bahwa berdasarkan cerita dari para peserta merasa cukup puas dengan acara tersebut. Berbeda dari pernyataan penyelenggara, menurut Muhammad Ihwan F, salah satu pemenang Insan PR 2018 yang diadakan secara langsung di Semarang ini mengatakan pandangannya terkait event JAMPIRO, yaitu:

"Kelebihannya mewah, nyaman, menemukan banyak ahli PR. Kekurangannya lama-lama monoton."

Dapat diambil kesimpulan bahwa antara pernyataan penyelenggara dengan para peserta berbeda. Oleh sebab itu diperlukan adanya formulir evaluasi tingkat kepuasan peserta saat mengikuti event tersebut. Hal ini agar mengurangi peluang adanya respon negatif dari peserta.

\section{Implementasi Event Jambore PR Indonesia (JAMPIRO)}

Event dapat menjadi tolak ukur keberhasilan menjadi seorang PR profesional di perusahaan. Menyelenggarakan event secara terus menerus, menjadikan stakeholder semakin mudah untuk mengetahui positioning perusahaan. Nantinya produk atau jasa tersebut akan melekat dan mudah diingat oleh stakholder (Puspitasari \& Dkk, 2017:117). Berikut adalah beberapa aspek yang menjadi penilaian PR Indonesia dalam menyelenggarakan suatu event:

\section{Manfaat}

Menyelenggarakan suatu event harus memiliki manfaat bagi para audiens-nya. Manfaat dalam sebuah event dibagi menjadi 3 yaitu:

\section{A. Memperoleh Informasi}

Berdasarkan hasil wawancara, diketahui bahwa peserta JAMPIRO baik yang dilaksanakan secara langsung maupun online memperoleh informasi yang dibutuhkan selama mengikuti acara JAMPIIRO. Seperti pernyataan Winda Adelita salah satu pemenang Icon PR 2020, ia mengatakan setelah mengikuti acara JAMPIRO ini merasa memperoleh banyak informasi terkait dunia PR serta dapat memperdalam hubungan dengan stakeholder. Ia berharap program yang sudah dijalankan oleh panitia dapat berjalan dengan baik. Berbeda dengan yang dikatakan oleh Erfina Ningsih Pasaribu sebagai salah satu pemenang Icon PR 2018. Erfina mengatakan bahwa:

"Memperoleh informasi sih lumayan ya karena banyak banget informasi tentang kehumasan yang baru saya tahu. Namun, untuk mengetahu lebih dalam, tidak sih, karena justru udah cari tau informasi mendalam ketika proses mau mengikuti acara tersebut"

Berdasarkan pernyataan diatas, sebelum dan sesudah mengikuti acara JAMPIRO, peserta sudah memperoleh informasi mendalam tentang PR Indonesia melalui website atau sosial media.

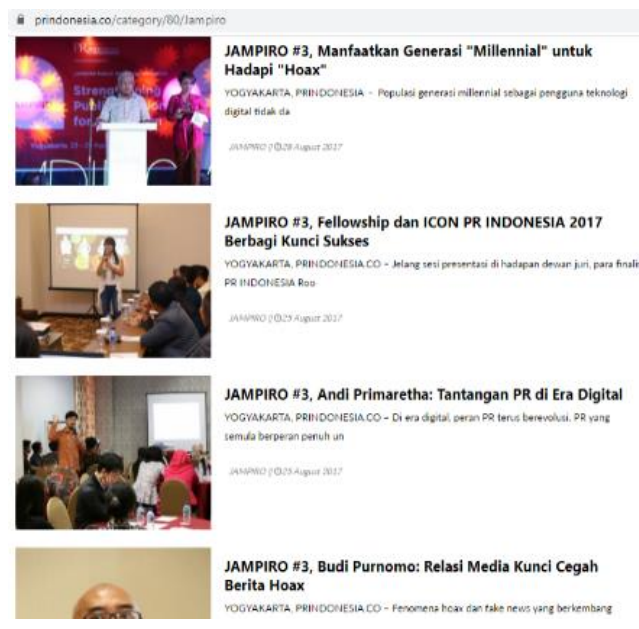

Gambar 1. Website terkait informasi JAMPIRO Sumber: Website PR Indonesia

Peserta memperoleh informasi secara mendalam terkait event JAMPIRO ini melalui website resmi PR Indonesia. Peserta mulai tertarik dengan kegiatan 
JAMPIRO dan mendaftar kompetisi tersebut. Selebihnya mengatakan memperoleh informasi yang dibutuhkan terkait dunia kehumasan setelah mengikuti acara. Berdasarkan hasil wawancara, dapat diambil kesimpulan bahwa tiap peserta memperoleh informasi tentang event JAMPIRO sesuai dengan kebutuhan masing-masing.

\section{B. Menunjukan Eksistensi}

Salah satu alasan penyelenggara event dalam melaksanakan suatu acara yaitu untuk menunjukan eksistensi baik kepada audiens maupun kepada kompetitor. Seperti yang dilakukan oleh Founder PR Indonesia dalam menunjukan eksistensinya kepada stakeholder yaitu dengan melihat apakah goals yang sedang dijalankan oleh perusahaan tercapai atau tidak. Hal ini dilihat dari performance dari sisi bisnis. Diukur dari portofolio produk, banyaknya jumlah peserta yang mengikuti event dari tahun ke tahun, jaringan dan pengikut di media sosial bertambah. Dari ukuran tersebut dapat memperoleh reputasi yang baik dan memperoleh brand reputation. Hal ini didukung oleh pernyataan penyelenggara event JAMPIRO. Lila Intana mengatakan cara menunjukan eksistensi melalui event JAMPIRO yaitu:

"Cara menunjukan eksistensi

ke stakeholder ya dengan

menjaga trust. Yaitu dengan

kulakan ide, bertemu dengan

berbagai stakeholder"

Dari kulakan ide bersama dengan para stakeholder tersebut, memberikan ruang kepada PR Indonesia untuk memperkenalkan programnya kepada stakeholder eksternal. Sehingga dapat memudahkan tim event dalam meningkatkan citra event tersebut dikalangan stakeholder. Sependapat dengan pernyataan founder dan penyelenggara event JAMPIRO, salah satu pemenang Icon PR 2020 yaitu

Krishna Pandu, mengatakan:

"Sudah tau PR Indonesia dan

event JAMPIRO melalui

media sosial, dan

sebelumnya juga pernah

mengikuti kompetisi lain.

Awal mulainya gara-gara

dari instansi Kementerian

Keuangan sering

mendapatkan penghargaan

dari event PRIA."

Berdasarkan pernyataan narasumber diatas, dapat diambil kesimpulan bahwa strategi atau cara yang dilakukan founder PR Indonesia dalam menunjukan eksistensi kepada stakeholder cukup berhasil. Sesuai pernyataan Krishna Pandu, ia mengetahui PR Indonesia melalui media sosial instagram.
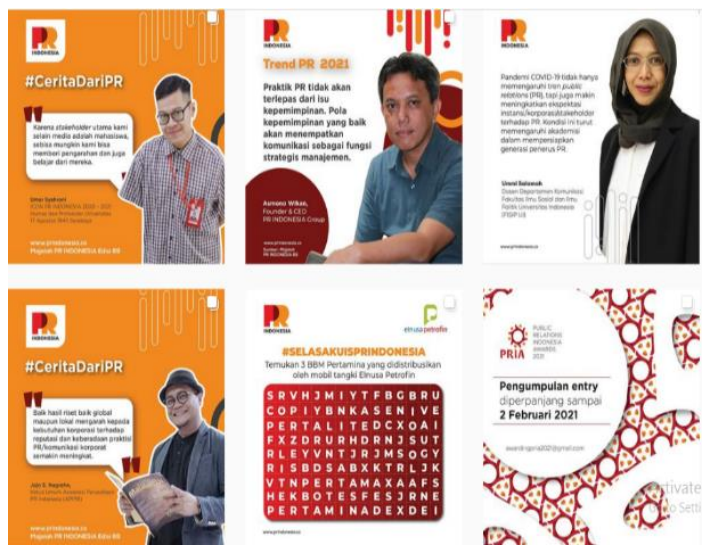

Gambar 2. Konten Instagram PR Indonesia Sumber: Instagram PR Indonesia

PR Indonesia dalam menunjukan eksistensinya juga memanfaatkan fitur konten yang ada di media sosial instagram. Dari fitur yang digunakan tersebut, dapat meningkatkan reputasi PR Indonesia di mata stakeholder dan membuat event yang ada di PR Indonesia semakin dikenali oleh banyak orang.

\section{Menjaga Reputasi}

Menyelenggarakan event di suatu perusahaan juga sebagai salah satu 
bentuk menjaga reputasi yang baik. Seperti yang dikatakan oleh founder PR Indonesia melalui wawancara yaitu:

"Dengan menghadirkan para tokoh di acara JAMPIRO dapat diukur acaranya baik, walaupun ada juga yang mengatakan kurang baik, tapi memang tidak ada yang sempurna dalam menyelenggarakan suatu event, tapi kami selalu improve dilihat dari antusias peserta semakin meningkat dari tahun ke tahun. Alhamdulillah service event yang kita berikan disambut baik oleh audiens. Dari situ kami menjaga reputasi."

Berdasarkan pernyataan Bapak Asmono Wikan selaku founder PR Indonesia, dapat diambil kesimpulan bahwa dalam menjaga reputasi yang baik cara yang dilakukan yaitu dengan mengelola suatu event yang diminati stakeholder. Serta selalu improve event dengan memberikan service yang baik agar peserta semakin meningkat dan reputasi perusahaan dapat terjaga dengan baik.

\section{Jenis}

Mengelola suatu event yang dapat disukai oleh audiens, diperlukan riset yang mendalam untuk mengetahui apa yang menjadi kebutuhan stakeholder. Menurut Getz, event dibagi menjadi empat jenis yaitu attraction merupakan event yang menjadi daya tarik tersendiri bagi target audiens. Atraksi juga merupakan suatu kegiatan yang menarik untuk dinikmati. Selanjutnya, image maker yaitu perusahaan dapat memasarkan programnya melalui event untuk memberikan kesan yang baik dan membentuk citra positif bagi perusahaan. Ketiga, animators of static attractions yaitu melalui suatu event dapat menunjukkan atraksi sebagai ajang kreativitas bagi si pembuat event. Serta yang terakhir adalah catalyst for other development, secara tidak langsung event merupakan penggerak tumbuhnya sektor lain agar membantu melengkapi kegiatan yang diselenggarakan. Berdasarkan jenis event diatas, Lila Intana selaku penyelenggara event JAMPIRO mengatakan:

"Hampir semua masuk karena based on need. Melihat dari kebutuhan praktisi PR. Mulai dari pelatihan, conference, lomba, city tour hingga awarding. "

Dapat diambil kesimpulan bahwa, event JAMPIRO masuk keempat jenis event tersebut. Sebab JAMPIRO dapat menjadi daya tarik tersendiri bagi audiens, juga sebagai sarana untuk mempromosikan produk majalah $\mathrm{PR}$ Indonesia kepada stakeholder, menjadi salah satu contoh ajang kreativitas dalam mengelola event kehumasan, serta membantu pemerintah daerah dalam menumbuhkan sektor pariwisata. Sebab event yang diselenggarakan oleh PR Indonesia selalu diadakan di Kota yang berbeda-beda setiap tahun.

\section{Kategori}

Mengelola suatu event, penyelenggara JAMPIRO perlu mengetahui kategori event yang akan diselenggarakan. Dibagi menjadi tiga yaitu mini event yang diikuti oleh kurang dari seratus ribu pengunjung dan bersifat lokal. Medium event, mengundang minimal satu juta pengunjung dan bersifat nasional. Mega event yang diikuti minimal lima negara dan bersifat internasional. Berdasarkan kategori diatas, Lila Intana mengatakan event JAMPIRO lebih mengarah ke kategori mini dan medium event yaitu dengan peserta kurang dari seratus ribu dan bersifat nasional.

Berdasarkan gambar diatas, peserta yang mengikuti event JAMPIRO 4 yang diadakan di Kota Semarang dihadiri oleh berbagai kalangan mulai dari mahasiswa hingga praktisi PR nasional. Hal ini 
sesuai dengan pernyataan Lila Intana bahwa JAMPIRO masuk kekategori mini dan medium event.
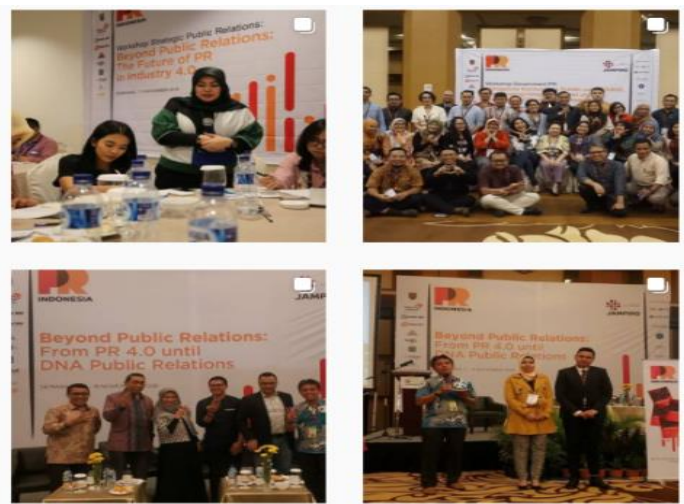

Gambar 3. Keseruan peserta event JAMPIRO 42018

Sumber: Instagram PR Indonesia

\section{Implementasi Virtual Event Jambore PR (JAMPIRO)}

Pandemi COVID-19 yang terjadi di Indonesia pada tahun 2020 sangat berdampak bagi seluruh korporasi. Salah satunya berdampak dalam menyelenggarakan suatu event. Sebab event menjadi salah satu ujung tombak korporasi agar produk atau jasa yang ditawarkan semakin dikenal oleh audiens dan stakeholder. Berkaitan dengan pandemi, PR Indonesia tetap menjalankan event-nya melalui online atau virtual. Tentunya dalam menyelenggarakan suatu event secara virtual sangat berbeda dengan yang diselenggarakan secara langsung. Mulai dari teknis acara, waktu, pendapatan, pengeluaran, dan lain sebagainya. Berikut adalah beberapa komponen yang masuk kedalam virtual event:

\section{Kriteria}

Menyelenggarakan suatu event secara virtual juga perlu mempersiapkan beberapa aspek seperti kriteria event. Kriteria tersebut meliputi flexibility yaitu menentukan platform yang menjadi wadah dalam acara yang disangkutkan dengan kubutuhan perusahaan. Lalu realibility, yaitu platform yang sudah dipilih harus terbuka setiap saat agar memudahkan panitia dalam memonitoring acara. Serta kriteria terakhir yaitu scalability, merupakan peningkatan skala peserta sehingga target peserta yang diharapkan oleh penyelenggara dapat tercapai. Lila Intana sebagai penyelenggara event JAMPIRO juga mengatakan demikian perihal kriteria dalam membuat virtual event JAMPIRO. Ia mengatakan:

"Pertimbangan ada zoom, gmeet, streaming youtube. Jadi dibuat perbandingan. Dulu youtube streaming belum ada awarding jadi dibuat di di youtube agar lebih menarik, kalau untuk zoom terlalu kaku dan ribet. Jadi main di proses kreatif dengan tapping awarding dan kapasitas penonton lebih banyak daripada di zoom."

Berdasarkan pernyataan Lila Intana, dapat diambil kesimpulan bahwa dalam menetukan kriteria platform perlu adanya riset pasar dan melakukan perbandingan antara satu platform dengan platform yang lain. Hal ini dilakukan agar lebih memikat audiens yang menonton serta akan membantu menambah jumlah target peserta.

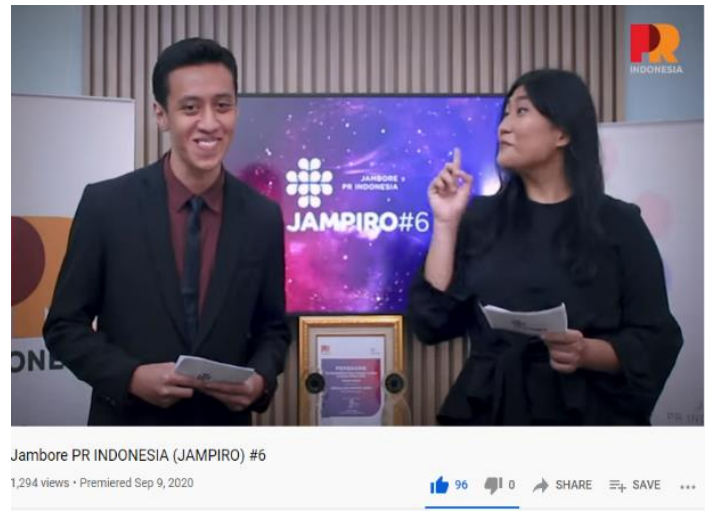

Gambar 4. JAMPIRO 6 Melalui Youtube Sumber: Youtube PR Indonesia

Memilih platform youtube memang cukup akurat, sebab banyak audiens yang dapat melihat acara tersebut dengan mudah. Serta dapat ditonton secara fleksibel dimanapun penonton berada. Memilih dan menentukan platform yang tepat juga dapat meningkatkan citra dan 
reputasi perusahaan dikalangan stakeholder.

\section{Perbedaan}

Mengelola vitual event tentunya berbeda dengan mengelola event secara langsung. Perbedaan yang sangat tampak saat menyelenggarakan virtual event yaitu berkaitan dengan anggaran, pendapatan dan waktu. Lila Intana selaku penyelenggara event JAMPIRO juga mengatakan:

"Anggaran juga lebih murah, namun lebih menguntungkan yg offline, Kalau online lebih mahal di creativenya.

Pendapatan berbeda, kalau online gabisa dijual mahal. Mulai dari durasi iya, Online harus lebih singkat gabisa lama2 nanti boring, maksimal 2 jam."

Perbedaan kebutuhan event memang sangat berdampak bagi pendapatan perusahaan. Walaupun pengeluaran untuk mengelola virtual event jauh lebih murah dibandingkan secara langsung, namun pendapatan yang dimiliki juga sangat berkurang. Serta dalam menentukan durasi acara berbeda dengan acara langsung. Sebab audiens paling lama melihat layar adalah 2 jam, berbeda dengan acara offline yang dapat dilakukan sehari penuh.

\section{Strategi PR Indonesia dalam Membangun Corporate Reputation Melalui Event Jambore PR Indonesia (JAMPIRO)}

Membangun reputasi yang baik di suatu perusahaan, hal utama yang perlu dipersiapkan yaitu strategi dari internal perusahaan. Strategi yang digunakan oleh perusahaan nantinya dapat membantu dalam meningkatkan reputasi dimata stakeholder. Reputasi dilakukan untuk mengukur sejauh mana perusahaan tersebut dilihat oleh stakeholder. Reputasi di dalam perusahaan sangat diperlukan agar dapat menjadi bahan evaluasi perusahaan tentang kinerja selama periode tertentu. Hal ini untuk menunjukkan posisi relatif baik secara internal dengan karyawan dan secara eksternal dengan stakeholder, baik dalam lingkup institusional maupun persaingan (Alexander, 2019:3).

Dapat diketahui bersama bahwa strategi yang dilakukan PR Indonesia dalam membangun reputasi perusahaan yaitu dengan mengadakan suatu event yang berkelanjutan. Event tersebut membantu perusahaan agar meningkatkan nama baik serta membantu memperkenalkan produk atau jasa yang akan ditawarkan kepada stakeholder. Berkaitan dengan adanya pandemi covid-19, membuat PR Indonesia harus terus berinovasi dan mempersiapkan solusi yang efektif. Inovasi memiliki definisi yaitu ssebagai penerapan keberhasilan dari proses kreatifitas perusahaan (Rahmawati, 2013:7). Seperti tetap mengadakan event yang berkelanjutan tetapi secara virtual. Hal ini dilakukan PR Indonesia agar reputasi yang sudah dibangun secara positif sejak awal tidak berubah akibat pandemi. Inovasi tersebut disambut baik oleh para peserta JAMPIRO, 7 dari 12 narasumber menilai bahwa event JAMPIRO ini dapat menjadi wadah peserta untuk mengembangkan bakat dan kemampuan untuk berjejaring dengan praktisi PR secara baik.

Strategi yang selalu dilakukan oleh PR Indonesia dan sudah menjadi pakem atau patokan setiap tahunnya dalam membangun corporate reputation melalui event JAMPIRO, antara lain melakukan city tour ke berbagai Kota yang ada di Indonesia agar event tersebut semakin dikenal, bersilaturahmi dengan para Kepala Daerah di masing-masing Kota agar mempermudah dalam menyelenggarakan event, menggunakan Icon PR sebagai brand reputation untuk mempromosikan berbag ai kegiatan khususnya event JAMPIRO kepada para stakeholder, dalam hal ini adalah stakeholder eksternal atau orang diluar perusahaan dan tidak terlibat langsung dalam kegiatan di korporasi (Maskuroh, 2014:195). Selain itu, berdiskusi dengan para praktisi PR tentang perkembangan dunia kehumasan agar menemukan ide dan 


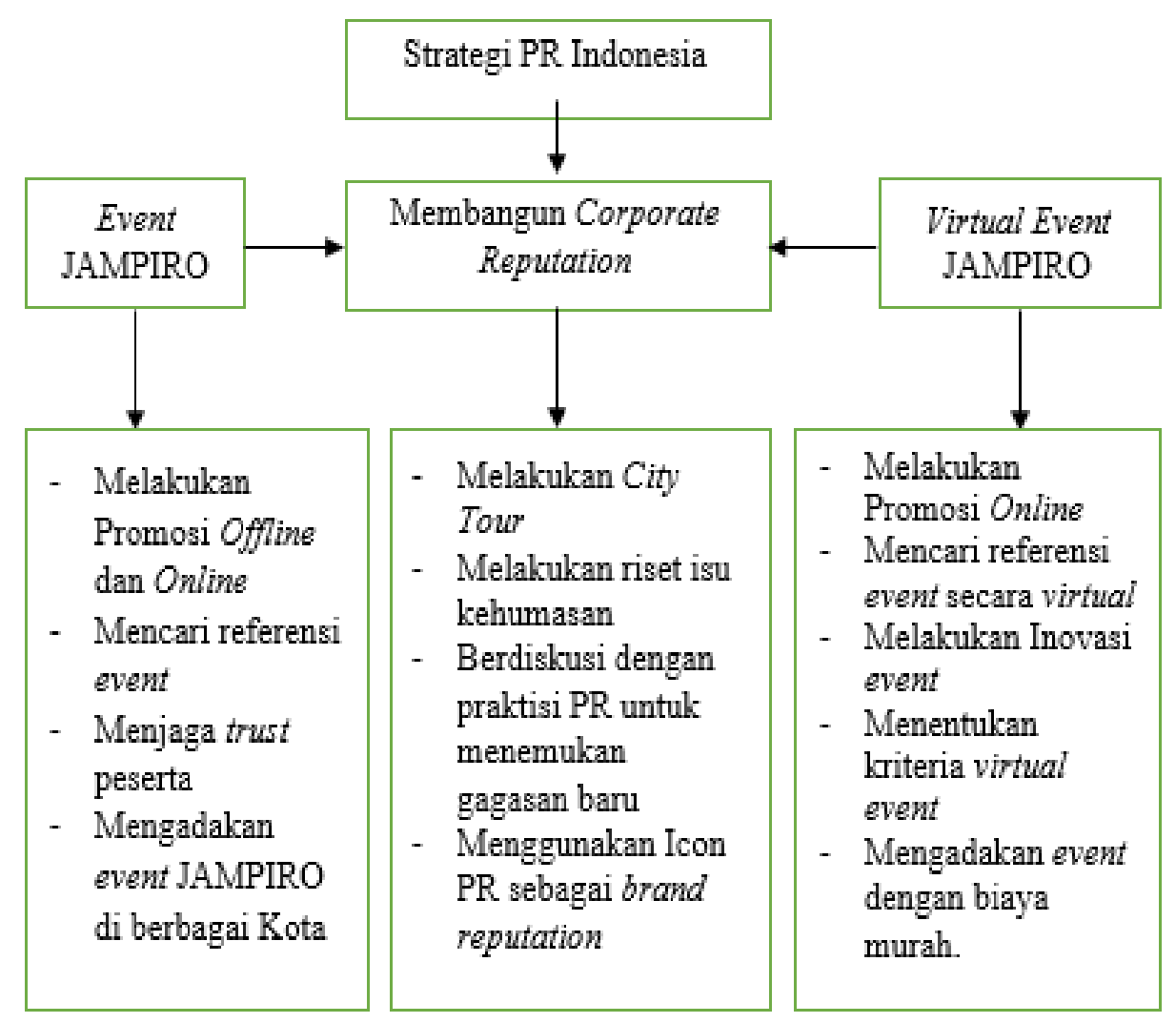

Gambar 6. Strategi PR Indonesia

gagasan yang baru serta melakukan riset dan brainstorming dengan panitia event JAMPIRO terkait isu kehumasan yang dapat diaplikasikan di acara tersebut.

PR Indonesia dalam merumuskan suatu ide atau tema di event tersebut juga memerlukan peran para praktisi PR. Sebab, praktisi $\mathrm{PR}$ juga memiliki peranan penting terkait perkembangan dunia kehumasan setiap tahunnya, sehingga event yang nantinya diselenggarakan lebih unik dan menarik. Strategi tersebut digunakan untuk menyatukan ide dan gagasan antara stakeholder internal maupun eksternal. Hal ini dilakukan agar tercipta suatu event yang dapat menguntungkan antara kedua pihak. Selain itu, pendekatan baik di level mahasiswa hingga level kepala daerah dilakukan oleh PR Indonesia sebagai bentuk strategi event tersebut, sebab JAMPIRO merupakan kompetisi yang menyasar keseluruh lapisan mahasiswa hingga kepala daerah. Semakin banyak pendekatan personal dilakukan maka semakin banyak peserta yang tertarik dengan event
JAMPIRO. Penggunaan Icon PR sebagai wajah PR Indonesia juga merupakan langkah yang tepat sebab Icon PR dapat menjadi influencer untuk menarik perhatian stakeholder. Dari strategi tersebut dapat menciptakan brand reputation atau reputasi merek yang dapat dilihat dari kredibilitas, kepercayaan, tanggung jawab dan kehandalan yang baik bagi PR Indonesia dikalangan stakeholder (Pratiwi, 2020:34).

Strategi yang digunakan PR Indonesia juga dapat membantu merumuskan event JAMPIRO agar semakin banyak orang yang mengikuti event tersebut setiap tahunnya, antara lain melakukan promosi baik secara offline maupun online agar informasi yang disampaikan lebih merata, menjaga trust atau kepercayaan peserta dengan memberitakan sesuatu yang positif sehingga dapat menarik perhatian peserta, melakukan tour ke berbagai instansi maupun korporasi serta ke universitas yang memiliki jurusan kehumasan atau ilmu komunikasi untuk memperkenalkan event JAMPIRO, mencari referensi event yang 
diminati oleh stakeholder. membuat berbagai rangkaian acara yang menarik agar peserta semakin tertarik, serta mengadakan event JAMPIRO di Kota yang berbeda agar tidak monoton dan peserta yang mengikuti semakin banyak hingga taraf nasional.

Berkaitan dengan adanya pandemi yang terjadi pada tahun 2020, PR Indonesia membuat inovasi event yang diadakan secara virtual. Kehadiran virtual event juga sebagai alternatif dan memberikan pengalaman yang baru dalam membuat suatu acara (Wreford, Williams, \& Ferdinand, 2019:721). Banyak sekali perbedaan saat mengelola event secara langsung dan virtual. Untuk merumuskan virtual event yang disukai stakeholder, maka PR Indonesia memiliki strategi yaitu melakukan promosi secara penuh melalui media sosial dan website PR Indonesia, memilih kriteria youtube streaming sebagai platform PR Indonesia untuk mengumumkan awarding competition, mengadakan rangkaian acara JAMPIRO dengan biaya pendaftaran yang jauh lebih murah agar audiens tetap tertarik untuk berpartisipasi, melakukan riset dan mencari referensi virtual event yang diminati audiens, dan yang terakhir melakukan inovasi dengan memberikan visualisasi event yang berbeda dari biasanya.

\section{Kesimpulan}

Reputasi korporat dibangun oleh PR Indonesia dengan beragam kegiatan, seperti city tour, melakukan riset isu kehumasan, dialog dengan praktisi PR, menempatkan Icon PR sebagai brand reputation. Jambore PR Indonesia tidak hanya sebagai event namun merupakan strategi dalam membangun corporate reputation. Pelaksanaan Jambore PR Indonesia yang awalnya offline, kini akibat dampak pandemi covid 19, berinovasi dengan virtual event agar reputasi perusahaan tetap berjalan dengan baik. Strategi PR Indonesia antara lain melakukan promosi melalui online, mencari referensi event secara virtual, melakukan inovasi event, menentukan kriteria virtual event dan mengadakan event dengan biaya murah.

\section{Referensi}

Adhrianti, L. (2018). Infografis Penguatan Reputasi Kehumasan Pemerintah melalui Narasi Tunggal Sosialisasi Paket Kebijakan Ekonomi. Jurnal ASPIKOM, 3(5), 1015. https://doi.org/10.24329/aspikom.v3i5. 273

Alexander, R. J. F. (2019). Analisa Pengaruh Location Influence, Physical Influence, Price Importance, dan Corporate Reputation Terhadap Residential Purchase Intention; Studi Kasus De Victory Regency Surabaya. Jurnal Strategi Pemasaran, 6(1), 12.

Estaswara, H. (2020). Defining Communication Problems in

Stakeholder Relations Based on Stakeholder Theory. Jurnal ASPIKOM, 5(1), 87. https://doi.org/10.24329/aspikom.v5i1. 540

Indrayani, H., Nurlita, R., \& Fitriani, J. D. (2020). Manajemen Strategis Public Relations: Teori dan Praktik Corporate dan Government Public Relations (A. Wikan, Ed.). Jakarta: PR Indonesia.

Mariana, N. A. (2012). Peran dan Strategi Public Relaltions Melalui Corporate Social Responsibility. Universitas Indonesia, Jakarta: Universitas Indonesia.

Marsyaf, M. I. (2020, July). Groovy EO Kenalkan Konsep Virtual Event di Masa COVID-19. Sindonews. Com.

Maskuroh, E. (2014). Kinerja Bank Syariah Dan Konvensional Di Indonesia (Vol. 11).

Pratiwi, M. (2020). Pengaruh Kualitas 
Produk, Brand Image dan Reputasi Terhadap Keputusan Pembelian Griya $i B$ Hasanah dengan Kepercayaan Sebagai Variabel Intervening. Institut Agama Islam Negeri Salatiga.

Puspitasari, Y. (2017). Peran Event dalam Pembentukan Citra Redline Management \& Talent School. Jurnal Transformasi, II(32), 116-121.

Rahma, A. (2017). Event Sebagai Salah Satu Bentuk Strategi Komunikasi Pemasaran Produk Fashion Nasional ( Event Tahunan Jakcloth ). Journal of Communications, 1(2), 149-169.

Rahmawati, I. N. (2013). Dampak Event Sepak Bola Dunia Terhadap Inovasi Produk dan Pemasaran Pada Home Industry di Kampung Batik Laweyan Solo (Vol. 66). Universitas Negeri Semarang.

Risna, I. (2019). Peran kepuasan pada pengaruh antara corporate reputation dan loyalitas nasabah. Universitas Muhammadiyah Malang.

Shiao, B. D. (2010). Virtual Events : Ready, Set, Go. Event (London), 20.

Sutopo, H. . (2002). Metodologi Penelitian Kualitatif. Surakarta: UNS Press.

Syahriani, D., \& Siwi, M. (2018). Hubungan Corporate Social Responsibility dengan Reputasi Perusahaan. Jurnal Komunikasi Pembangunan, 16(1), 5474.

TSNN. (2010). 2010 Virtual Event Report: Insights \& Trends From Industry Insders.

Tzanelli, R. (2017). In: Mega-Event Mobilities: A critical analysis (S. V. den B. Noel B. Salazar, Christiane Timmerman, Johan Wets, Luana Gama
Gato, Ed.). UK.

Wreford, O., Williams, N. L., \& Ferdinand, N. (2019). Together alone: An exploration of the virtual event experience. Event Management, 23(4), 721-732. https://doi.org/10.3727/152599519X 15506259855625 